\title{
Malformation of the tail in Labrador Retriever dogs caused by mutation C189G in the T gene ${ }^{1}$
}

\author{
Diego M. Silva², Gabriela G.P. Miguel ${ }^{3}$, Michelli L. Souza ${ }^{4}$, Herbert P.K. Cleveland ${ }^{5}$ \\ and Carlos A.N. Ramos ${ }^{6 *}$
}

\begin{abstract}
Silva D.M., Miguel G.G.P., Souza M.L., Cleveland H.P.K. \& Ramos C.A.N. 2018. Malformation of the tail in Labrador Retriever dogs caused by mutation C189G in the T gene. Pesquisa Veterinária Brasileira 38(12):2237-2240. Faculdade de Medicina Veterinária e Zootecnia, Universidade Federal de Mato Grosso do Sul, Av. Senador Filinto Muller 2443, Vila Ipiranga, Campo Grande, MS 79070-900, Brazil. E-mail: carlos.nascimento@ufms.br

The present study reported the mutation C189G in the T gene (Brachyury gene) as the cause of malformation in the tail of the Labrador dog. One litter of Labradors, from a mating between a female with short tail and a male with normal tail admitted at the Veterinary Teaching Hospital of Universidade Federal de Mato Grosso do Sul, Campo Grande, Brazil, was evaluated in this study. Blood samples were collected from the female and her puppies. After DNA extraction, sequencing and PCR-RFLP were carried out. The C189G mutation was identified through both techniques only in dogs with short tail.
\end{abstract}

INDEX TERMS: Malformation, tail, Labrador Retriever, dogs, mutation C189G, T gene, genotyping, hereditary diseases.

\begin{abstract}
RESUMO.- [Malformação da cauda em cães da raça Labrador Retriever causada por mutação C189G no gene T.] No presente trabalho relata-se a mutação C189G no gene T (Brachyury gene) como causa da malformação da cauda em cães da raça Labrador. Uma ninhada de labradores, provenientes do acasalamento entre uma fêmea com a cauda curta e um macho com a cauda normal, encaminhados ao Hospital Veterinário da Universidade Federal de Mato Grosso do Sul, Campo Grande, Brasil, foi avaliada nesse estudo. Amostras de sangue da cadela e filhotes foram coletadas. Após extração de DNA, sequenciamento e PCR-RFLP foram
\end{abstract}

\footnotetext{
${ }^{1}$ Received on March 24, 2018.

Accepted for publication on May 2, 2018.

${ }^{2}$ Student of Veterinary Medicine, Faculdade de Medicina Veterinária e Zootecnia, Universidade Federal de Mato Grosso do Sul (UFMS), Av. Senador Filinto Muller 2443, Vila Ipiranga, Campo Grande, MS 79070-900, Brazil.

${ }^{3}$ Student in Animal Science, Faculdade de Medicina Veterinária e Zootecnia, UFMS, Av. Senador Filinto Muller 2443, Vila Ipiranga, Campo Grande, MS 79070-900.

${ }^{4}$ Post-Graduate Program in Veterinary Medicine, Faculdade de Medicina Veterinária e Zootecnia, UFMS, Av. Senador Filinto Muller 2443, Vila Ipiranga, Campo Grande, MS 79070-900.

${ }^{5}$ Laboratório de Biologia Molecular, Faculdade de Medicina Veterinária e Zootecnia, UFMS, Av. Senador Filinto Muller 2443, Vila Ipiranga, Campo Grande, MS 79070-900

${ }^{6}$ Professor, Faculdade de Medicina Veterinária e Zootecnia, UFMS, Av. Senador Filinto Muller 2443, Vila Ipiranga, Campo Grande, MS 79070-900. *Corresponding author: carlos.nascimento@ufms.br
}

realizados. A mutação C189G foi identificada por meio de ambas as técnicas apenas nos cães com a cauda malformada.

TERMOS DE INDEXAÇÃO: Malformação, cauda, caninos, Labrador Retriever, mutação C189G, gene T, genotipagem, doenças hereditárias.

\section{INTRODUCTION}

Dogs with congenital tail malformation have been known for a long time (Pullig 1953). However, the etiology was long unknown.

Studies conducted by Haworth et al. (2001) and Hytönen et al. (2009) found association of a mutation in exon 1 of T gene (UniProtKB - Q9GL27), which encodes a transcription factor and tail malformation in many dog breeds (Cocker Spaniel, Bichon Frisé, Setter, Golden Retriever, Dachshund, Shih-tzu, Yorkshire, Fox). This mutation is the substitution of a cytosine for a guanine at nucleotide 189 of the gene (C189G), which causes a change from isoleucine to methionine at amino acid 63 of the encoded protein. The transcription factor encoded by the $\mathrm{T}$ gene is important for the normal embryonic development of the posterior mesoderm (Haworth et al. 2001), an embryonic tissue that will give origin to somites that will later originate the vertebrae and the tail (Hyttel et al. 2012).

Dogs with only one mutant allele (heterozygotes) have short tail or total tail absence. As homozygous animals have not been observed for the mutant allele described above, it has been proposed that when in homozygosis, mutation 
is lethal (GG genotype), causing the death of animals even during gestation or soon after birth (Haworth et al. 2001, Indrebo et al. 2008).

Although Labrador dogs were evaluated in previous studies, the presence of the mutation was not identified (Haworth et al. 2001). The present study reports the identification of the C189G mutation in Labrador dogs and its association with tail malformation.

\section{MATERIALS AND METHODS}

Animals and samples. 10 dogs from the mating between a congenital short-tailed Labrador Retriever female and a male of the same breed with normal tail were used. The female used in the mating was primiparous, and all the animals evaluated came from the city of Campo Grande, Mato Grosso do Sul, Brazil. The dogs were taken to the Veterinary Hospital of the Federal University of Mato Grosso do Sul for routine examinations and genetic counseling in May 2016. With regard to tail, pups presented the following phenotypes: 4 with normal tail, 4 with short tail, and 2 with absence of the tail.

A venous blood sample with EDTA was collected from the mother and from each of the ten pups from that crossing for further analysis.

All evaluated dogs were owned by a non-profit private breeder.

Genetic analysis. Blood samples were submitted to extraction of genomic DNA according to protocol recommended by Araújo et al. (2009). After extraction, DNA samples were evaluated for integrity and absence of PCR inhibitors by $1 \%$ agarose gel electrophoresis and PCR for constitutive gene ( $\beta$-actin) (Wang et al. 2007).

Primers 5'-AGAGCCTGCAGTACCGAGTG-3' and 5'-CCGAGACTTCTCCCAGAAAA-3' developed by Hytonen et al. (2009) were used to amplify a 384bp fragment comprising part of exon 1 and intron 1 of canine $\mathrm{T}$ gene. Reactions were carried out in a volume of $50 \mu \mathrm{l}$ containing $10 \mathrm{mM}$ Tris-HCL ( $\mathrm{pH} 8.3$ ), $50 \mu \mathrm{M}$ of $\mathrm{KCl}$, $1.5 \mathrm{mM} \mathrm{MgCl}, 0.2 \mathrm{mM}$ of each dNTP, $1.25 \mathrm{U}$ of Taq DNA polymerase (Ludwig Biotec), 11pmol of each primer, and approximately 100 $\mathrm{ng}$ of genomic DNA. Thermocycling occurred at $94^{\circ} \mathrm{C}$ for four minutes, followed by 30 cycles at $94^{\circ} \mathrm{C}$ for one minute, $60^{\circ} \mathrm{C}$ for 30 seconds and $72^{\circ} \mathrm{C}$ for another 30 seconds. A final step of extension at $72^{\circ} \mathrm{C}$ for three minutes was performed.

Amplified fragments were submitted to digestion (PCR-RFLP) with BstEII enzyme (Promega) for two hours at $60^{\circ} \mathrm{C}$. The digestion product was visualized in UV transilluminator after 3\% agarose gel electrophoresis. Based on in silico restriction analysis performed with the aid of NEBcutter software (Vincze et al. 2003), the expected fragments were $189 \mathrm{bp}$ and $195 \mathrm{bp}$ in normal individuals, homozygous genotype (CC), and 195bp, 158bp and 31bp in heterozygous individuals (CG).

In addition, amplified DNA fragments from 4 animals, 1 normal and 3 with tail alteration were purified with CleanSweep PCR Purification (Thermo Fisher Scientific) according to manufacturer's recommendations and submitted to sequencing in both directions, with primers described above in ABI-3130 sequencer (Apllied Byosistems).

The sequences were analyzed with the aid of the BLASTn (Altschul et al. 1990), MEGA 7 (Kumar et al. 2016) and CodonCode Aligner software (CodonCode Corporation).

\section{RESULTS AND DISCUSSION}

PCR-RFLP analysis revealed restriction patterns compatible with in silico analysis. All dogs with tail malformation presented the same pattern ( 3 fragments, 2 visible bands), which was different from that presented by dogs with normal tail ( 2 fragments, 1 visible band) (Fig.1). Another assay, also

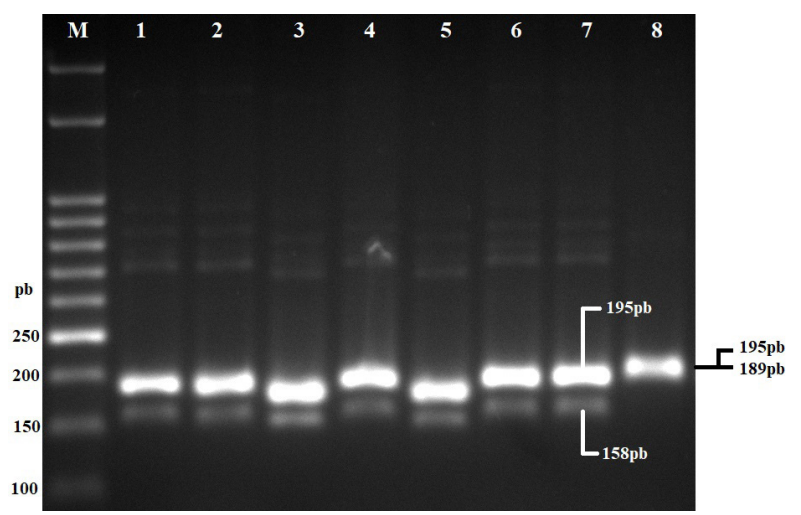

Fig.1. PCR-RFLP for detection of C189G mutation. Marker of base pairs (M), affected dogs - short tail (1-7) and animal with normal tail (8).

based on PCR-RFLP, was successfully used to identify the same mutation in the $\mathrm{T}$ gene of dogs, but using a polyacrylamide gel electrophoresis system (Gruszczynska \& Czapla 2011). The performance of the polyacrylamide gel electrophoresis could improve the resolution of bands relative to DNA fragments in the present study. However, practicality would be reduced, since this system is more laborious. In the present study, even though it was not possible to visualize all the DNA fragments generated after digestion, it was possible to easily distinguish genotypes using agarose gel electrophoresis.

In the analysis of sequenced samples, heterozygosity $\mathrm{C}$ (cytosine) G (guanine) was observed in nucleotide 189 of exon 1 only in dogs with tail malformation. The location of the mutation was based on the T gene mRNA sequence available in the Genbank (accession number: AJ245513).

At the in silico analysis, alteration of amino acid 63 from isoleucine to methionine was also observed. All DNA sequences obtained in the present study were deposited in Genbank under accession numbers: MF495488 (short tail), MF495489 (absence of tail), MF495490 (absence of tail) and MF495491 (normal tail).

Although only one genotype was found for the present condition (CG for animals with tail malformation), a phenotypic variation was observed in affected dogs, which is the tail size. Some animals presented short tail (approximately 3-4 vertebrae), and others showed absence of tail (approximately 1-2 vertebrae) (Fig.2). Similar phenotypes were also observed by Haworth et al. (2001) in dogs. Although an explanation for this is not yet known in dogs, Buckingham et al. (2013), studying congenital tail size variation in cats, found evidence of haploinsufficiency caused by multiple mutations in the T gene. C.1199delC, c.1169delC and c.998delT mutations were associated with different levels of gene expression, which could explain the different phenotypes among dogs with tail malformation (Buckingham et al. 2013).

The hereditary character of the mutation can be evidenced by the heredogram analysis (Fig.3) of the litter studied. It was possible to verify that the mutation has an autosomal dominant inheritance pattern. However, no dominant homozygous (GG) genotype was found in the present study, reinforcing the observations that when in homozygosis, the mutated T gene causes fetal death (Haworth et al. 2001). Hytonen et al. (2009) 


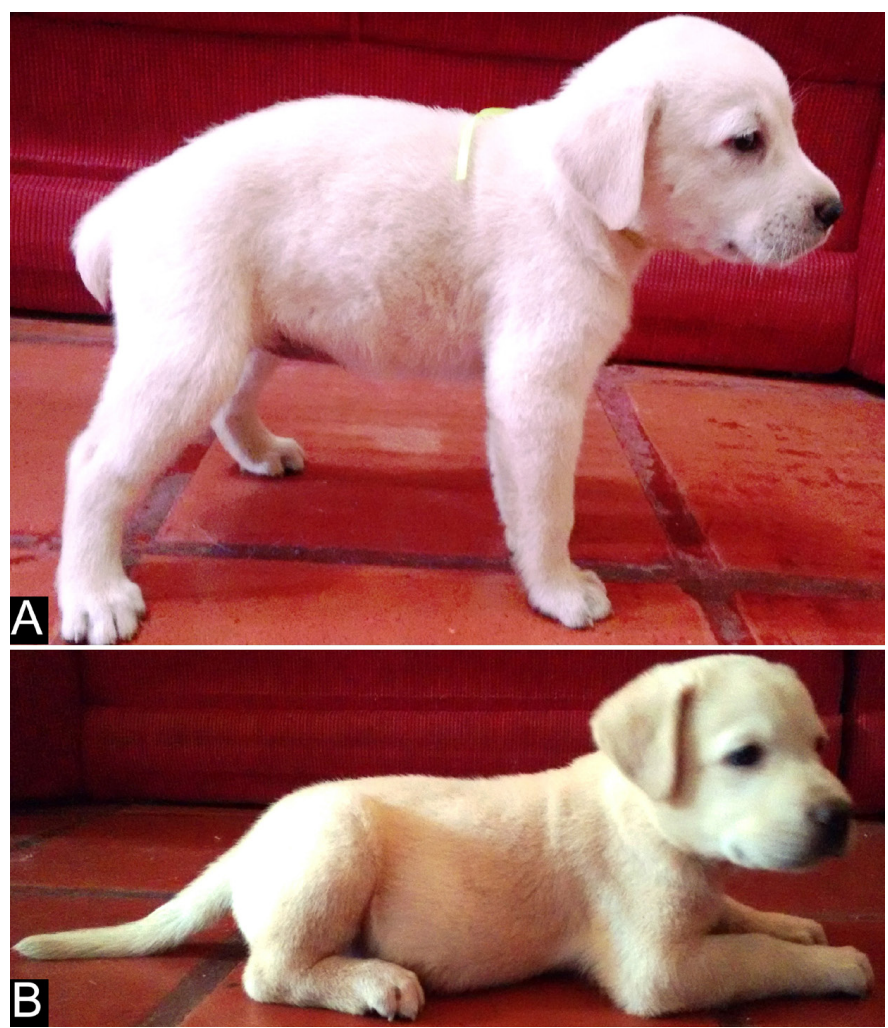

Fig.2. (A) Dog carrying mutation C189G in the T gene. (B) Dog from the same litter without $\mathrm{C} 189 \mathrm{G}$ mutation.

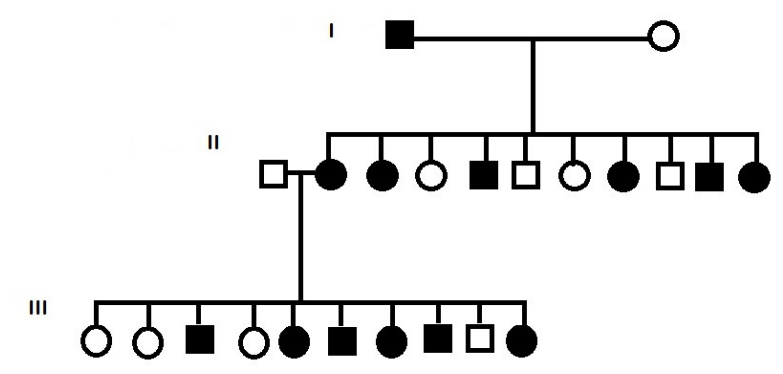

Fig.3. Heredogram showing the inheritance pattern of the C189G mutation in the $\mathrm{T}$ gene of Labrador Retriever. Crossbreeding between maternal grandparents (I), litter of the affected dog and its crossing with normal male (II) and litter analyzed (III).

observed that litters from crosses between normal-tailed animals (CC genotype) were 29\% larger than litters from crossbreeding between malformed tail animals (CG genotype). This result is compatible with the expected reduction of $25 \%$ in offspring from crosses involving lethal alleles.

Mutations in the $\mathrm{T}$ gene have been associated with tail malformation in other species such as mice and cats (Wilson et al. 1995, Buckingham et al. 2013). And in some of them, other changes are also observed, such as urinary and fecal incontinence in cats (Robinson 1993). However, in dogs, to date, only tail malformation has been observed in heterozygous animals (CG) (Indrebo et al. 2008). Although in some canine breeds the "tail malformation" phenotype was not associated with the C189G mutation (Boston Terrier, English Bulldog, King Charles Spaniel, Miniature Schnauzer, Parson Russell Terrier, and Rottweiler), the large number of breeds affected suggests an ancient mutation (Hytonen et al. 2009), being present in ancestral dogs before the formation of many breeds. However, interracial crossbreeding may also have contributed to the mutation diffusion, since CG heterozygous animals appear to have no libido or reproductive performance alterations. Another factor that may have contributed to mutation diffusion was the use in the reproduction of dogs without tail, when esthetic caudectomy was still permitted. In this period, it is likely that many animals with tail agenesis have been used as reproducers, since tail absence was desirable in some breeds, contributing to the mutation diffusion.

Currently, the practice of caudectomy (surgical tail removal) is a prohibited procedure in several countries of the world such as those of the European Union and Brazil (Haworth et al. 2001, CFMV 2013). In some European Union countries, genetic tests to identify the C189G mutation in the $\mathrm{T}$ gene are used to verify if the absence of tail in some breeds is of congenital origin or the animals underwent irregular surgical procedure. PCR-RFLP used in the present study was a simple and accurate technique to identify this mutation and could be used as evidence to identify illegal caudectomy practice.

Due to the scarcity of information about the $\mathrm{C} 189 \mathrm{G}$ mutation in the T gene of dogs, there is no further information regarding its association with other morphological or even physiological characters, and therefore needs to be investigated.

\section{CONCLUSION}

The present study confirms the occurrence of C189G mutation in the $\mathrm{T}$ gene of Labrador Retriever dogs and its association with tail malformation.

Acknowledgements. The authors are grateful to Universidade Federal de Mato Grosso do Sul for the financial support (EDITAL PROPP/UFMS No. 111/2018).

\section{REFERENCES}

Altschul S.F., Gish W., Miller W., Myers E.W. \& Lipman D.J. 1990. Basic local alignment search tool. J. Mol. Biol. 215(3):403-410. <http://dx.doi. org/10.1016/S0022-2836(05)80360-2><PMid:2231712>

Araújo F.R., Ramos C.A.N., Luiz H.L., Peres I.A.H.F.S., Oliveira R.H.M., Souza I.I.F. \& Russi L.S. 2009. Avaliação de um Protocolo de Extração de DNA Genômico a Partir de Sangue Total. Comunicado técnico 120, Embrapa Gado de Corte, Campo Grande. 5p.

Buckingham K.J., McMillin M.J., Brassil M.M., Shively K.M., Magnaye K.M., Cortes A., Weinmann A.S., Lyons L.A. \& Bamshad M.J. 2013. Multiple mutante T alleles cause haploinsufficiency of brachyury and short tails in Manx cats. Mamm. Genome 24(9/10):400-408. <http://dx.doi.org/10.1007/s00335013-9471-1> <PMid:23949773>

CFMV 2013. Resolução 1027 de 18 de junho de 2013. Conselho Federal de Medicina Veterinária. Available at <http://portal.cfmv.gov.br/portal/ legislacao/index/pagina/2?titulo-descricao-resumo=2013\&categorias $\%$ 5B\%5D=todas\&ordenacao=numero> Accessed on Jun. 29, 2017. 
Gruszczynska J. \& Czapla A. 2011. A molecular test for the detection of the C295G mutation in the T gene responsible for shortened tail and taillessness in the Pembroke Welsh Corgi. Anim. Sci. 49(49):35-43.

Haworth K., Putt W., Cattanach B., Breen M., Binns M., Lingaas F. \& Edwards Y.H. 2001. Canine homolog of the T-box transcription factor T; failure of the protein to bind to its DNA target leads to a short-tail phenotype. Mamm. Genome 12(3):212-218. <http://dx.doi.org/10.1007/s003350010253> <PMid:11252170>

Hytönen M.K., Grall A., Hedan B., Dréano S., Seguin S.J., Delattre D., Thomas A., Galibert F., Paulin L., Lohi H., Sainio K. \& André C. 2009. Ancestral T-Box mutation is present in many, but not all, short-tailed dog breeds. J. Hered. 100(2):236-240. <http://dx.doi.org/10.1093/jhered/esn085> <PMid:18854372>

Hyttel P., Sinowatz F. \& Vejlsted M. 2012. Embriologia Veterinária. Elsevier, Brasil. 472p.

Indrebø A., Langeland M., Juul H.M., Skogmo H.K., Rengmark A.H. \& Lingaas F. 2008. A study of inherited short tail and taillessness in Pembroke Welsh Corgi. J. Small Anim. Pract. 49(5):220-224. <http://dx.doi. org/10.1111/j.1748-5827.2007.00435.x> <PMid:17850278>
Kumar S., Stecher G. \& Tamura K. 2016. MEGA7: molecular evolutionary genetics analysis Version 7.0 for bigger datasets. Mol. Biol. Evol. 33(7):18701874. <http://dx.doi.org/10.1093/molbev/msw054><PMid:27004904>

Pullig T. 1953. Anury in cocker spaniel. J. Hered. 44(3):105-107. <http:// dx.doi.org/10.1093/oxfordjournals.jhered.a106364>

Robinson R. 1993. Expressivity of the manx gene in cats. J. Hered. 84(3):170172. <http://dx.doi.org/10.1093/oxfordjournals.jhered.a111311> $<$ PMid:8228170>

Vincze T., Posfai J. \& Roberts R.J. 2003. NEBcutter: a program to cleave DNA with restriction enzymes. Nucleic Acids. Res. 31(13):3688-3691. <http:// dx.doi.org/10.1093/nar/gkg526> <PMid:12824395>

Wang Y.S., Chi K.H. \& Chu R.M. 2007. Cytokine profiles of canine monocytederived dendritic cells as a function of lipopolysaccharide or tumor necrosis factor-alpha-induced maturation. Vet. Immunol. Immunopathol. 118(3/4):186-198. <http://dx.doi.org/10.1016/j.vetimm.2007.05.010> $<$ PMid:17617471>

Wilson V., Manson L., Skarnes W.C. \& Beddington R.S. 1995. The T gene is necessary for normal mesodermal morphogenetic cell movements during gastrulation. Development 121(3):877-886. <PMid:7720590> 